\title{
Prosoodiast meloodiani - eestikeelse Piibli proosatekstil põhineva ühehäälse a cappella kirikulaulu ehk eesti pühalaulu metodoloogia
}

\author{
Eerik Jõks \\ Eesti Muusika- ja Teatriakadeemia lektor ja teadur \\ eerik@ekn.ee
}

\begin{abstract}
Teesid: Eestis enimlevinud eestikeelne kirikulaul on stroofilisel värsstekstil põhinev luterlik koraal. Lääne kirikulaulu kirjaliku traditsiooni juured (9.-10. saj) on aga Piibli proosatekstidel põhinevas kirikulaulus (PPK). Tänapäeval on emakeelne PPK ehk pühalaul naasmas luterlikku lauluvarasse. Artiklis näitan, kuidas eesti keele prosoodia parameetritega arvestamine saab kaasa aidata eesti keele pärase PPK loomisele ja viljelemisele, ehk kirjeldan printsiipide süsteemi, ${ }^{1}$ mille järgimisel sünnib stilistiliselt mitmekesine eestikeelne pühalaul. Pühalaulu kontemplatiivse, deklaratiivse ja vaba stiili kirjeldamine näitab, et tegu on suurte võimalustega žanriga, mis vääristab meie emakeele prosoodiat, tunnustab traditsiooni, millest meie muusikakultuur võrsub, ja annab väärika positsiooni eesti kirjakeele ning kultuuri tüvitekstile - Piiblile.
\end{abstract}

Märksõnad: emakeel, gregooriuse laul, keskaegne sakraalne ladina monoodia, kirikumuusika, liturgiline laul, Piibel, prosoodia, psalm, pühalaul

\section{Sissejuhatus}

\subsection{Kontekst}

Eestlased on pea viissada aastat elanud luterliku dominandiga kristliku kultuuriruumi tingimustes ja seega on igati arusaadav, et eestikeelne kirikulaul seostub eelkõige luterliku koraaliga, mida kiriklaulu mõisteaparaadis nimetatakse ka hümniks. ${ }^{2}$ Seepärast on mõisted "koraal" ja "hümn" selles artiklis kasutusel sünonüümidena. Koraalid, nii nagu ka suur osa vaimulikku koorimuusikat luterlikus kultuuriruumis, põhinevad stroofilistel värsstekstidel, mille kõik salmid on lauldavad sama viisiga. Kui aga vaadata Lääne kirikulaulu tervikuna, siis selgub, et varaseima (kirjaliku) kirikulaulu sõnaliseks aluseks oli ladinakeelse Piibli proosatekst ja ennekõike Vana Testamendi (VT) laulude ehk psalmide tekstid ja/või nende parafraasid. 
VT psalmid olid heebrea algkeeles luulevormis, aga ladinakeelses tõlkes ja eriti kirikulaulu kontekstis - on need käsitletavad proosana. Sarnaselt võib proosana käsitleda ka heebrea keelest tõlgitud ja praegu kõige laiemalt kasutatavaid eestikeelseid VT psalme (Piibel 1999). Selle väite üle võib muidugi vaielda ja jääda õigustatud eriarvamusele, et ka tõlkepsalmid on endiselt värsid. Kindlasti aga ei ole need samalaadsed koraali ehk hümni stroofiliste värssidega, milles kõik salmid on lauldavad sama viisiga. Erandiks on psalmitõlked, mida on meelega püütud seada stroofiliseks värsstekstiks. ${ }^{3}$ Selliselt tõlgitud psalmi eeliseks on saadud teksti lauldavus hümnina, aga selle puuduseks on ilmselge tõsiasi, et täpselt sama silpide arvuga värsiridadeks seadmise tõttu tuleb teha järeleandmisi algupärase teksti arvelt. Proosa-laadselt tõlkides on teksti algupäraga arvestamise võimalused suuremad. Niisiis vastanduvad teksti viisistamise põhimõtete seisukohalt (1) stroofiline värsstekst, mis koosneb kindlaksmääratud silpide arvuga värsiridadest, ja (2) teised tekstid - proosahümn, vabavärss, proosa - ehk üldistavalt proosatekst, millel sellist korrapära ei ole. Kõik teise kategooria tekstid alluvad viisistamisel proosateksti põhimõtetele. Seepärast ongi antud kontekstis põhjust käsitleda eestikeelseid tõlkepsalme, sh selles artiklis esitatud näiteid proosatekstina. Samuti annab selleks põhjust tõik, et sageli kasutatakse miniatuurse kompositsiooni, nt antifooni tekstina vaid ühte lauset pikemast tekstist, mis võib tervikuna olla käsitletav värsstekstina, aga iseseisva lausena vastab kasutatav segment igal juhul proosateksti tunnustele.

Põhjus, miks algkogudus just VT psalmidega tugevat sidet tundis, seisneb kindlasti algkristluse kokkupuutes juutlusega, aga ka selles, et Naatsareti Jeesus ise andis eeskuju VT psalmidega palvetamiseks. ${ }^{4}$ Pealegi ei olnud esimese sajandi alguses, mil ristikirik tekkis, veel UT (kirjalikke) tekste, mida jumalateenistuslikus elus kasutada. Algkoguduse poolehoid VT psalmidele peegeldub varajase Lääne kirikulaulu tekstikorpuses ja seob ka tänase ristikiriku tugevalt nende tekstide külge.

Nõnda oligi 9.-10. sajandil esmakordselt kirjalikult fikseeritud Lääne kiriku lauluvara valdavalt proosatekstiline, sest kirikulaulu sõnadeks kasutati põhiliselt tekste Piiblist - tsitaate või parafraase; järkjärgult hakkas selle kõrvale tekkima erinevaid uusi, stroofilise värsstekstiga kompositsioone, nt sekventsid; luterliku reformatsiooni tagajärjel 16. sajandil tõrjus emakeelne stroofiline värsstekst proosa luterliku kirikulaulu tekstikorpusest valdavas mahus välja; 20.-21. sajandil on aga emakeelne Piibli proosatekstiline kirikulaul (PPK) ehk pühalaul naasmas luterlikku lauluvarasse. Sellest kõnelevad laulupsaltrid erinevate luterlike kirikute lauluraamatutes, nt (1) Baieri ja Tüüringi 1994. aasta "Evangeelne lauluraamat" (Baier \& Tüüring 1994) sisaldab proosatekstilise kirikulaulu sektsiooni - sellele on pühendatud $6,3 \%$ 
raamatu mahust - või (2) 2015. aastal ilmunud "Läti Evangeelse Luterliku Kiriku lauluraamat" (Läti 2015), millest lätikeelsele PPK-le on pühendatud lausa 17,5\% raamatu mahust. Ka Eesti Evangeelse Luterliku Kiriku (EELK) uue koostatava lauluraamatu, mis peaks ilmuma 2024-2025, lähteülesandes ${ }^{5}$ on ühe uuendusena ette nähtud psaltri lisamine lauluraamatusse. ${ }^{6}$

Keskaegne sakraalne ladina monoodia $(\mathrm{KSLM})^{7}$ kui Euroopa esimene kirjalik muusikaline repertuaar seadis 9. ja 10. sajandil paika teksti ja muusika omavahelise seose lähtepunkti Euroopa kirjalikus (professionaalses) muusikakultuuris. Ladina prosoodia ja KSLMi seostest inspireerituna olen möödunud kaheteistkümne (eriti süvenenult viimase kuue) aasta jooksul püüdnud leida praktilist lahendust pakkuvaid seoseid eesti keele prosoodia ja emakeelse Piibli proosatekstilise kirikulaulu loomise, õpetamise ja viljelemise vahel. Töö käigus on välja joonistunud kolm PPK stiili: (1) kontemplatiivne stiil, (2) deklaratiivne stiil ja (3) vaba stiil. Stiilide kirjeldamine ei ole mul olnud eraldiseisev taksonoomiline eesmärk. Pigem on olnud tegu vajadusega luua PPK tutvustamiseks ja õpetamiseks struktureeritud pilt selle mitmekesisest tervikust. Minu kirjeldatud stiile on võimalik rakendada ka KSLMi repertuaari liigitamiseks, aga need on ennekõike kasutamiseks siiski emakeelse kirikulaulu kontekstis.

\subsection{Põhimõisted}

Kuna ma tegelen "silla ehitamisega" prosoodia ja meloodia vahel interdistsiplinaarses kontekstis, olgu siinkohal defineeritud silla mõlemad pead. Prosoodia on keeleteaduses koondmõiste, mis hõlmab kõnelõikude kestuse, hääle valjuse ja kõrgusega seotud nähtusi (Vääri et al. 2000: 806). Kaisa Häkkineni järgi on prosoodilised ehk suprasegmentaalsed tunnused kestus, rõhk ja kõrgus (Häkkinen 2007: 83). Meloodia on ühehäälselt väljendatud muusikaline mõte (Kostabi \& Semlek 1976: 89). Sama määratluse üks autoritest Leo Semlek on aastal 2003 kirjutanud veel, et "järgnevatest helidest moodustub meloodia kui helijärgnevus" (Semlek 2003: 53). ${ }^{8}$ Laad on tugihelide ümber organiseerunud helide kogum (Kostabi ja Semlek 1976: 57).

Termini pühalaul määratlemine ei ole ühemõtteliselt ja lõplikult praegu veel võimalik, sest mõiste tähendusväli on alles kujunemisjärgus ja ilmselt on selle lõplik sisustamine veel ees, muidugi kui see termin meie kirikulaulu mõisteruumi üldse kinnitub (Jõks 2017). Mõiste kujunemisel võib saada oluliseks küsimus selle ulatusest: (1) kas pühalaul on ainult eesti keele keskne või võib seda laiendada ka teistes keeltes kirikulaulule, nt KSLM oleks siis keskaegne ladina pühalaul; (2) kas mõistet "pühalaul” peaks ikka piirama vaid muusikaga, mis põhineb Piibli tsitaatidel ehk proosal, või peaks see mõiste laienema ka 
hümni- ehk koraalimuusikale, mille stroofilised värsstekstid otseselt parafraseerivad ja/või seletavad Piibli proosat. Nt eestikeelne luterlik koraal oleks siis "stroofiline eesti pühalaul". Ma ei soovi siinkohal selle mõiste sisustamist monopoliseerida, vaid teen avalikuks tulemuse, milleni olen oma töös tänaseks jõudnud. Loodan tulevikus laiema diskussiooni tekkimisele asjakohastes kogukondades, mille tulemiks on mõiste adekvaatne ja ammendav sisustamine.

Kui me räägime keeleteaduse spetsiifikast lähtudes, siis "pühalaul on kolme prosoodilise parameetri: (1) kestuse ehk temporaalsuse, (2) valjuse ehk dünaamilisuse ja (3) kõrguse ehk intonatsiooni tähelepanelik vaatlemine Piibli tekstide lausumisel ja nende parameetrite märkamine ning nendega arvestamine meloodiajoonise kujunemisel ning selle esitamisel” (Jõks 2017).

Kuna pühalaul on ennekõike vaimulik tegevus, siis olgu siinkohal ära toodud ka sellest spetsiifikast lähtuv definitsioon. "Vagadusliku määratluse kohaselt võib öelda, et pühalaul on põhiosas Piibli (valdavalt muutmata kujul) tekstide keskendunud või pühaliku veendumusega palvemeelne, enamjaolt ühehäälne ja üldjuhul instrumentaalsaateta ( c cappella) muusikaline lausumine, püüdes alluda täielikult ja igakülgselt Jumala Sõna autoriteedile ning arvestades kasutatava keele eripärasid" (Jõks 2017).

Pühalaulu võiks teiste sõnadega nimetada ka keelemuusikaks. Ma ei seleta sissejuhatuses mõisteid "kontemplatiivne stiil", "deklaratiivne stiil" ja "vaba stiil”, sest nende määratlusteni on otstarbekam jõuda teema lahkamise kaudu artikli kolmandas osas.

\subsection{Artikli eesmärk ja töö põhjendatus}

Artikli eesmärk on kirjeldada metodoloogiat, mis võimaldab juurutada Piibli proosatekstilist kirikulaulu ehk pühalaulu Eesti kirikumuusika praktikasse, toetudes (1) emakeelse Piibli proosatekstile, (2) Lääne kirikulaulu traditsiooni varaseimale kihistusele ehk KSLMile ja (3) tekstikesksele mõtlemisele ning eesti keele prosoodiale. Metodoloogia on sündinud aastatel 2005-2017 interdistsiplinaarses kontekstis, hõlmates muusikateaduse, teoloogia ja keeleteaduse areaale.

Eestikeelse pühalaulu juurutamine on vajalik, et teadvustada meie muusikaja kogu vaimukultuuri sügavamaid juuri, sh Lääne kiriku algupärast traditsiooni pidada jumalateenistusi enamjaolt kiriku tüviteksti ehk Piibli proosatekste võimalikult sõnasõnaliselt kasutades. Kui on soov seda traditsiooni teadvustada, siis tekib vajadus rakendada kirikulauludes neidsamu Piibli proosatekste neid eelnevalt stroofilisteks värsstekstideks teisendamata. Eestikeelne antifoonide ja responsooriumide repertuaar selles vallas on küll erinevate kirikumuusikute 
tegevusest olemas (nt Riho Ridbek, Ene Salumäe, Margo Kõlar, Tuuliki Jürjo, Mart Siimer, Eerik Jõks ja mitmed teised), aga ei ole veel piisavalt mitmekesine, küllaldaselt teadvustatud ega kättesaadav. Eesti keele prosoodia spetsiifikat arvestava psalmilaulu temaatikaga ei ole minu teada varem üldse tegeletud. Kõikidele kättesaadav ja jõukohane pühalaulu didaktiline materjal puudub.

Pühalaulu metodoloogia tutvustamiseks kirjeldan artiklis ülevaatlikult mõnede näidete alusel kolme pühalaulu stiili, mis on minu praktilises tegevuses välja joonistunud: (1) otsin ühendust prosoodia ja meloodia vahel kontemplatiivse stiili kontekstis ja meloodiavormelitel põhineva pühalaulu abil; (2) demonstreerin mõningate näidete varal teekonda prosoodiast meloodiani deklaratiivse stiili abil ja "kõnekurvide meetodit" kasutades; (3) näitan, kuidas deklaratiivses stiilis pühalaulu antifooni saab täiendada vaba stiili raamistikus. Selle artikli keskne küsimus on: kas ja kuidas saab eesti keele prosoodia parameetritele keskendumine kaasa aidata eesti keelele omase kirikulaulu loomisele ja viljelemisele?

Ma ei pea vajalikuks hakata siinkohal polemiseerima teemal, kas psalmitekstilise lauluvara tagasitoomine luterlikku kirikusse on põhjendatud. ${ }^{9}$ Selline suundumus on eelpooltoodud lauluraamatute näidetel olemas. Küll aga tuleks vastata küsimusele, kas meile esmapilgul eelkõige rooma-katoliiklikuna tunduv muusikaline aines ikka sobib eestlaste seas enimlevinud luterlikku praktikasse. KSLMist võrsuva, sh vormelitel põhineva eestikeelse pühalaulu kasuks räägivad mitmed argumendid, millest mõned siinkohal esitan. Argumendid ei ole loetletud tähtsuse järjekorras.

(1) Praktiline argument. Läänekirikliku, meloodiavormelitel põhineva ladina pühalaulu näol on olemas terviklik, traditsiooniline ja toimiv süsteem proosatekstide laulmiseks elik muusikaliseks lausumiseks. Seda on vaid vaja eesti keele prosoodiast lähtudes kohandada. Mulle ei ole teada ühtegi teist sellist süsteemi, millega saaks proosatekste kollektiivselt ja lihtsakoeliselt laulda, ilma neid viisistamise jaoks modifitseerimata ehk stroofiliseks värsstekstiks teisendamata. Vormelite muusikaliseks materjaliks on aga võimalik kasutada mistahes ainest, nt regilaulu meloodikat (vt joonis 6), ja esituskoosseisuks kõike, mida fantaasia võimaldab, alates saateta ühehäälsusest kuni kuitahes suurte ja mitmehäälsete vokaal-instrumentaalsete koosseisudeni.

(2) Kirikulooline argument. KSLMist võrsuvat emakeelset pühalaulu seostatakse mõnevõrra põhjendamatult eelkõige rooma-katoliiklusega, mis omakorda võib leida vastandamist luterlusele. Kui 10. sajandil vormelitel põhinev psalmilaul esimest korda kirjalikult fikseeriti (vt Bailey 1979), siis ei olnud roomakatoliiklikku ja luterlikku vastuseisu veel olemas. Hilisematest reformaatoritest tuntum vend Martin Luther (1483-1546) elas ja kujunes augustiinlasest 
mungana just sellise, vormelitel põhineva psalmilaulu monastilises keskkonnas. Vaadates tänapäeval KSLMist võrsuvat emakeelset pühalaulu ei ole määravaks mitte rooma-katoliiklik dominant vaid läänekiriklik dominant. See on luterlaste kui Lääne kiriku ühe haru vaimne pärand - miks siis mitte seda kasutada.

(3) Oikumeeniline argument. Isegi kui keegi näeb KSLMil põhinevas emakeelses pühalaulus rooma-katoliiklikku dominanti - kordan veel kord, et mina seda seal ei näe -, ei ole 21. sajandil enam kohta luterluse ja rooma-katoliikluse viis aastasada kestnud vastandumisele, kuigi ajaloolisest inertsist võib seda veel ette tulla. Luterlik ja rooma-katoliiklik kogukond on bilateraalselt nii Vatikani ja Luterliku Maailmaliidu tasemel kui ka EELK peapiiskopi Urmas Viilma ja Eesti rooma-katoliku piiskopi Philippe Jourdan' tasemel ulatanud teineteisele ametliku ja avaliku vennakäe. ${ }^{10}$ Seoses reformatsiooni 500. aastapäevaga on Vatikani ja Luterliku Maailmaliidu poolt initsieeritud luterlaste ja roomakatoliiklaste ühtsuse komisjon koostanud dokumendi "Konfliktist osaduseni", mille tekstis võtavad luterlased ja roomakatoliiklased endale viie oikumeenilise imperatiivi näol mitmeid kohustusi. Esimene imperatiiv ütleb: "tugevdamaks seda, mis on ühine, peavad katoliiklased ja luterlased alati lähtuma ühtsuse ja mitte lõhenemise vaatenurgast [---]" (Teder \& Lääs 2017: 82). Kolmas imperatiiv kohustab: "Katoliiklased ja luterlased peavad uuesti pühenduma nähtava ühtsuse otsimisele [---]" (Teder \& Lääs 2017: 83). KSLMi traditsiooni tarkuse kui Lääne kiriku ühise pärandi kasutamine emakeelses kirikulaulus võiks ju imperatiivides kirjeldatud püüdlusteks suurepäraselt sobida.

\section{Lähtekohad}

\subsection{Emakeelse pühalaulu idee alus}

Emakeelse pühalaulu idee minu tegevuses sai alguse professor Godehard Joppichi (snd 1932) esitatud hüpoteesist keskaegse sakraalse ladina monoodia, eriti aga frangi-rooma laulu ehk gregooriuse laulu meloodiate tekkemehhanismi tuuma kohta. Hoolimata oma fantastilisusest ja ilmselt ka tõestamatusest on see mulle tunnetuslikult üks usutavamaid hüpoteese. Miks ma ütlen "tekkemehhanismi tuum", mitte aga "keskaegse kirikulaulu meloodiate tekkimine"? Nimetatud meloodiline informatsioon kirjutati 9.-10. sajandil üles vähemalt mitusada aastat pärast meloodiate tekkimist suulise pärimuse kontekstis ja kannab paksu kultuurkihi "kasukat", millest meloodiate algset tekkimist ühemõttelise selgusega ja tõestatavalt ei ole tõenäoliselt võimalik leida. Seepärast jääb Joppichi hüpotees ilmselt alatiseks hüpoteesiks, aga see-eest vägagi inspireerivaks hüpoteesiks. Joppich ütleb 2005. aastal antud intervjuus: 
Me peaksime küsima, "Mis on gregooriuse laulu [ehk frangi-rooma laulu] algupära”. Kas on võimalik, et üks muusik ilmus 8. sajandil frangi munkade kloostrisse ja ütles: "Te hääldate [ladinakeelseid] sõnu nii halvasti. Andke mulle kõik oma tekstid ja ma komponeerin teile ilusad meloodiad ja siis te saate laulda." Me peame küsima, kas gregooriuse laulu algupära sai olla "estethica musicale"-8. sajandi kultiveeritud muusikaline mõtlemine?

Mungad teadsid kõiki tekste mälu järgi, sest nad kordasid neid päevast päeva. Me teame, et kõik 150 psalmi ja kogu Uus Testament oli munkadel peas. Nad ei óppinud neid tekste lugedes - neil ei olnud raamatuid. Nad oppisid tekste, kuna vanem munk lausus neid neile ja ütles [Godehard loeb peast [üsna ükskõikselt] Püha Johannese Evangeeliumi alguse]: "In principio erat Verbum, et Verbum erat apud Deum, et Deus erat Verbum. Hoc erat in principio apud Deum. Omnia per ipsum facta sunt, et sine ipso factum est nihil, quod factum est; in ipso vita erat, et vita erat lux hominum, et lux in tenebris lucet, et tenebrae eam non comprehenderunt."11

Sadade aastate jooksul õppisid mungad tekste ainult nõnda. Vanem munk luges neile tekste, aga ta ei hääldanud ainult sõnu - ta hääldas oma usku, kuid seda mitte oma isiklikust arusaamisest lähtuvalt. Ta hääldas seda, mida ta ise oli ühelt vanemalt mungalt kuulnud, kes omakorda kuulis seda jälle oma eelkäijalt. Keegi ei söandanud muuta ka pisimat nüanssi, sest kui sa muudad kõla, siis muudad ka tähendust. Tänapäeval ei saa me trükkida ühtegi raamatut pühade tekstidega ilma põhjaliku toimetamise ja korrektuurita. Trükitud tekstis ei tohi olla ühtegi viga ja päris kindlasti ei tohi tekste muuta. Ei ole võimalik, et helilooja tuli [keskajal] ja ütles: "Ma olen kirjutanud teile: [Godehard laulab esimese advendipühapäeva algussalmide antifooni “Ad te levavi” alguse].” See muusika oli olemas juba sadu aastaid. See eksisteeris sõnade kõlas. Minu jaoks on gregooriuse laul sõnades leiduva muusika panemine inimhäälele sobivasse kõrgusesse, ei enamat. Mungad suutsid seda teha koos - nad olid leidnud sobiva meloodia, mis vastas õpitud sõnadele. Kui ma ennist laususin Püha Johannese Evangeeliumi algust, siis tegin ma seda nõnda [ükskõikselt] spetsiaalselt sinu intervjuu salvestise jaoks. Kui vanem munk seda teksti noviitsidele hääldas, siis ütles ta enamat. [Godehard loeb uuesti sama teksti, aga seekord oluliselt valjemalt ja teatava õpetusliku kavatsusega.]

Kui sa usud, et sulle on antud Rõõmusõnum [Evangeelium] - Uus Leping -, siis sa ka hääldad seda vastavalt. Meie jaoks ei ole see enam rõõmusõnum. Neil sõnadel ei ole meie jaoks kõla, sest meil on liiga vähe usku, et anda neile piisavalt kõla. Peab olema rohkem usku, et hääldada neid sõnu nii, nagu neid peaks hääldama. Gregooriuse laul on minu jaoks elumuutvate sõnade hääldamine inimhäälele sobivas kõrguses, mitte ainult teatava informatsiooni edastamine ${ }^{12}$ (Jõks 2009: 398-399). 
Joppichi idee tuum seisneb selles, et suulise traditsiooni olukorras, kui ei olnud piisavalt kirjalikke materjale ega lugemisoskust ja olulisi tekste anti edasi kuulmise järgi, ei õpetatud järgnevale põlvele mitte ainult tekste, vaid ka seda, millise intonatsiooniga neid lausuda. Põlvest põlve edasi antud tekstid, mis kandsid kiriku universaalset usku, kristalliseerusid aja jooksul meloodiateks ning fikseeriti käsikirjades Euroopa erinevates piirkondades märkimisväärse sarnasusega.

Ladina prosoodia roll gregooriuse laulus ei ole Joppichi avastus. Seda on esile tõstetud juba oluliselt varem, selle repertuaari kaasaegse taassünni või täpsemalt öeldes kaasaegse gregooriuse laulu sünni esimeste ämmaemandate poolt 19. sajandil, mil näiteks Augustin-Mathurin Gontier ütles, et reegel, mis domineerib kõikide reeglite üle, välja arvatud puhtmeloodilistes melismides, ütleb, et gregooriuse laul seisneb intelligentses lugemises, mis on hästi aktsenteeritud, hästi fraseeritud ja hea prosoodiaga (Gontier 1859: 14). Mis on aga Joppichi puhul originaalne, on tõdemus, et universaalne kristlik usk ladestus intonatsioonides ja kandus nõnda edasi järgnevatele põlvedele, kuni see erinevates Euroopa piirkondades lõpuks sarnaselt üles kirjutati. Joppichi hüpoteesist saigi alguse minu kõnekurvide meetod emakeelses pühalaulus, mis omakorda viis kontemplatiivse stiili aluspõhimõtete taipamiseni.

\subsection{Senised tööd}

Eestis ei ole meie emakeele prosoodial põhineva pühalauluga süstemaatiliselt varem tegeletud. Mulle ei ole ka teada, et rahvusvaheliselt oleks keegi sellist tööd Piibli proosatekstilise kirikulaulu kohta oma emakeele kontekstis teinud. Selle üks põhjusi võib olla tõsiasi, et erinevalt eesti keele prosoodiast on indoeuroopa prosoodiareeglite sobivus olemasolevate ja laialt tuntud gregooriuse ehk frangi-rooma laulu meloodiavormelitega täiesti piisav. Meloodiavormelitel põhineva pühalaulu, põhiliselt psalmilaulu, materjale on Eestis eelkõige erinevate koolituste läbiviimiseks mõnevõrra koostatud ja paljundusmaterjalidena levitatud. Täiesti uuenduslik nii vormilt, metoodikalt kui mahult on kolmest osast koosnev sektsioonraamat "Eesti laulupsalter" (ELP) (vt ka joonis 4). ${ }^{13}$

ELP on avatud köitega kolmest samaaegselt eraldi lehitsetavast jaotusest koosnev A4 formaadis pidevalt täienev sektsioonraamat. (1) Alumises jaotuses ehk psaltris on indekseeritud silpidega Vana Testamendi laulud ja valik Uue Testamendi kantikume; (2) keskmises jaotuses ehk tonaariumis on toonid ehk muusikalised vormelid psaltri tekstide laulmiseks elik muusikaliseks lausumiseks; (3) ülemises jaotuses ehk antifonaariumis on lühikesed muusikapalad - antifoonid ning responsooriumid. Psaltri 
tekstide silbid on teksti liigenduskohtade lõpust kümne silbi ulatuses indekseeritud ja meloodiavormeli vastavad noodid tonaariumis on nummerdatud. Laulmisel tuleb tekstis ja tonaariumis olevad numbrid kokku viia. Tekstide ja toonide kokkukuuluvus on universaalne kõik tekstid sobivad kõikide vormelitega. ELP erineb kogu senisest pühalaulualasest tegevusest Eestis, sest selles on pü̈̈tud hüljata ladina prosoodia põhimõtted ja rakendada eesti keele prosoodiareegleid (Jõks 2017).

Kui aga rääkida eesti keele prosoodia ja teksti ning muusika koosmõjude uurimisest, siis tuleb nimetada Taive Särgi tööd "Eesti keele prosoodia ning teksti ja viisi seosed regilaulus", mis sisaldab ka eesti prosoodia uurimisloo põhjalikku käsitlust (Särg 2005). Särg toob välja ühe olulise aspekti prosoodia uurimise varasest etapist:

Esimesed eesti keeleteadlased olid võõramaalased, kes vaatlesid eesti keele prosoodilist süsteemi indoeuroopa keelte põhjal välja kujunenud malli järgi. [---] Vana prosoodiakäsitluse esindajad arvasid omaaegsete teoreetiliste teadmiste, kuid võib olla ka saksa keelest lähtuva kuulamiskogemuse põhjal, et sõnarõhuga kaasneb pikendus, mistõttu kõiki eestikeelsete sõnade esisilpe peeti pikkadeks (Särg 2005: 202).

See tõsiasi on ennast sügavalt sisse kirjutanud ka eestikeelsesse luterlikku kirikulaulu, mis suures mahus pärineb saksa kultuuriruumist.

\subsubsection{KSLMi stiilid: süllaabiline, neumaline ja melismaatiline stiil}

Kuna selles artiklis liigitub eestikeelne pühalaul kolme stiilikategooriasse, siis kirjeldan ka ühte olemasolevat KSLMiga seotud liigitust, mis omab mõningast kokkupuutepunkti emakeelse pühalaulu stiilidega. KSLMis tuntakse kolme stiili: (1) süllaabiline, (2) neumaline või neumaatiline ja (3) melismaatiline (vt nt Apel 1958: 201-203; Siitan 1989: 18). (1) Süllaabilises stiilis vastab ühele silbile üldjuhul üks noot; (2) neumalises stiilis vastab enamikule silpidest kahest, kolmest, neljast või enamast noodist koosnev grupp, kusjuures ühte gruppi kujutavat graafilist notatsioonikujundit nimetatakse neumaks (sellest ka nimetus neumaline stiil); (3) melismaatilises stiilis võib ühe silbi kohta olla koguni kolmkümmend või rohkem nooti, mis moodustavad melismi. Pühalaulu stiilidest lähtudes saaks luua järgneva seose: (1) kontemplatiivne stiil on valdavas mahus süllaabiline, kadentsides sageli neumaline; (2) deklaratiivne stiil on samuti süllaabiline koos mõningate neumalise stiili elementidega; (3) neumaline ja eriti melismaatiline stiil seostuvad eelkõige vaba stiiliga. 


\section{Pühalaulu kolm stiili}

\subsection{Kontemplatiivne stiil (seesmiselt vaatlev, mõtisklev, endassesüüvinud)}

\subsubsection{Kontemplatiivse stiili iseloomustus}

Pühalaulu stiilide seletust oleks loogiline alustada kontemplatiivsest stiilist, sest see on kolmest stiilist tehniliselt kõige lihtsam ja nii KLSMi kui emakeelse pühalaulu praktikas kõige mahukam. ${ }^{14}$ Ometi saab seda stiili kõige piltlikumalt ja tulemuslikumalt seletada just deklaratiivse stiili tunnuste kaudu. Kõigile on teada lihtne tõsiasi, et kõneldes intoneerub inimese hääl üles ja alla. See lisab edastatavale sõnumile tõlgendusvarjundeid, väljendab meeleolu ja tundeid. Sarnaselt muudele tunnetele saab hääle intonatsioon väljendada ka religioosseid tundeid ja Joppichi hüpoteesi kohaselt võisid intonatsioonis väljendunud tunded olla tähenduslikud Lääne keskaegse kirikulaulu meloodilise informatsiooni kujunemisel (vt ptk 2.1). Mis aga juhtub, kui me "lülitame" lausumisel välja oma isikliku tõlgenduse ja hakkame lausuma silpe ühel helikõrgusel? Selle fenomeni lokaliseerimiseni jõudsin Joppichi hüpoteesi eestikeelsete tekstidega läbi katsudes, ja see on siiamaani kõige hämmastavam ahaa-elamus minu pühalaulualases tegevuses, sest see pakub seletust läänekirikliku meloodiavormelitel põhineva pühalaulu olemusele. Nimelt, kui me seame eesmärgiks eemaldada oma lausumisest kogu isiklik intonatsiooniline tõlgendus ja jätta alles ainult "puhas tekst", hakates lausuma silpe ühel helikõrgusel, tekib olukord, mille kohta mõni ütleks, et kõne on muutunud intonatsiooniliselt monotoonseks, aga tegelikkuses sarnaneb tulemus peaaegu äravahetamiseni ühel helikõrgusel laulmisega. See on foneetiline eksperiment, mida igaüks saab järele proovides kontrollida ja tulemuste õigsuses veenduda. Millised on selle fenomeni foneetiliselt mõõdetavad tunnused ning kas ja kuidas seda kognitiivse muusikateaduse kontekstis kirjeldada, jääb järgmiste uurimuste kanda.

Väga oluline on silmas pidada, et teatav monotoonsus tekib sellises olukorras siiski ainult ühe prosoodia parameetri ehk helikõrguse poolest, aga mitte kestuse ja valjuse poolest, kui neid just teatavast mentaalsest inertsist monotoonseks ei forsseerita. Tegelikult jääb lausumine ühel helikõrgusel kestuse ja valjuse poolest endiselt väljenduslikuks, tundlikuks ja varjunditerohkeks.

See ongi pühalaulu kontemplatiivse stiili alus, mida mõnevõrra ülekohtuselt nimetatakse ka retsiteerimiseks või retsitatiiviks (vt nt Hiley 1993: 47; Apel 1958: 21). Mis on siis retsiteerimise ja ilma isikliku intonatsioonilise tõlgenduseta ehk kõikide silpide ühel helikõrgusel lausumise vahe? Retsiteerimisel on olemas laulja kavatsus hakata laulma ja ennast laulu kaudu väljendama. Kontemplatiivse lausumise juures seda kavatsust aga ei ole - retsitatsioonile 
sarnane kõla tekib prosoodilise intonatsiooni "väljalülitamise" tagajärjel iseeneslikult. Retsitatiivis on oluline muusikaline ehk horisontaalne kavatsus ehk fraseerimine, võiks isegi öelda, et see on kaaluka tähtsusega; kontemplatiivsel lausumisel on domineeriv vertikaalne kavatsus ehk sõnade väljaütlemine, spetsiaalne muusikaline fraseerimine ei ole oluline.

\subsubsection{Pühalaulu meloodiavormeli baasülesehitus}

Pikki tekste on aga raske lausuda vaid ühel helikõrgusel ja selleks võetaksegi nii KSLMis kui emakeelses pühalaulus appi meloodiavormelid ehk toonid, et teksti liigendada. ${ }^{15}$ Valdav osa vormelitel põhinevat pühalaulu hõlmab VT psalme. Täpselt samasuguse ülesehitusega vormelite põhjal lauldakse aga ka UT kantikume, nt Maarja kiituslaul. ${ }^{16}$ Sarnaseid elemente leidub ka meloodiavormelites, mis on mõeldud muude pühakirjatekstide, nt epistli laulmiseks. Seepärast kasutan oma tekstides üldistavat mõistet "pühalaulu (meloodia) vormel” või "pühalaulu toon", ja peenhäälestan neid vajalike täienditega, nt "UT kantikumivormel" või "VT psalmivormel".

Meloodiavormeleid on lihtsamaid ja keerulisemaid, aga nad kõik alluvad samale baasülesehitusele. Kõik toonid koosnevad kahest poolest, mis on sageli eraldatud tärniga. Pooled omakorda jagunevad järgmisteks elementideks: (1) alustus, põhiheli, poolitus, põhiheli, vahepeatus, (2) (mõnel puhul ka teine alustus), (mõnel puhul ka teine) põhiheli ja lõpetus. Vormeli üks tsükkel katab tavaliselt ühe VT psalmi või UT kantikumi salmi, aga väga lühikeste salmide puhul liidetakse salme kokku ja väga pikkade salmide puhul võib esineda salmide poolitamist (vt nt joonis 4 , salmid 4 ja 5).

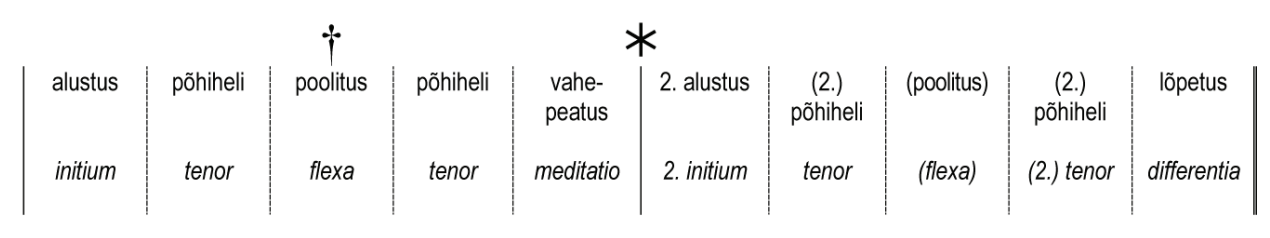

Joonis 1. Pühalaulu meloodiavormeli baasülesehitus.

Eestikeelsed mõisted (joonisel 1) olen ladinakeelsete eeskujul kasutusele võtnud seoses Pühalaulu Kooli ${ }^{17}$ tegevusega, kus on vaja lihtsat ja arusaadavat emakeelset terminoloogiat. Keskaegsest traditsioonist on vormeli osiste ladinakeelseid nimesid meieni kandunud teisigi (vt nt Siitan 1989: 5). 
Joonis 1 kujutab kõiki võimalikke osiseid, mis pühalaulu meloodiavormelil võivad esineda. Tegelikkuses need tavaliselt kõik koos ei esine. Nt VT psalmide ja UT kantikumide puhul ei kasutata traditsiooniliselt kunagi teist poolitust; teine põhiheli pärast vahepeatust esineb traditsioonilistes vormelites vaid paaril korral.

\subsubsection{Ekskurss aktsentuaalse ja kursiivse kadentsi temaatikasse ${ }^{18}$}

Gregooriuse laulu ehk frangi-rooma laulu helivormeleid, nii nagu need on publitseeritud Vatikani 19. ja 20. sajandi väljaannetes,${ }^{19}$ kasutatakse kogu maailmas, sh ka Eestis, emakeelsete tekstidega. ${ }^{20}$ Koos ladina vormelite ülevõtmisega on kaasa tulnud ka ladina prosoodia põhimõtete kasutamine vahe- ja lõpukadentsides ("vahepeatus" ja "lõpetus"). Ladina keeles, nii nagu ka paljudes teistes indoeuroopa keeltes on sõna rõhulisim silp üldjuhul tunnetatud pika silbina (vt ka ptk 2.2). See määrabki ladina pühalaulu aktsentuaalsete kadentsidega vormelite loogika: rõhulise ja ühtlasi pikana tunnetatud silbiga markeeritakse alati nii vahepeatuse kui lõpetuse muusikaliselt domineerivaid noote. Sellest ka mõiste "aktsentuaalne kadents". See tähendab aga, et silpide arv pärast kadentsi rõhulist nooti või noote (võib esineda ka kahe rõhuga kadentse nagu nt lõpetus joonisel 2) varieerub ja vormelis tuleb kasutada vajadusel rakendatavaid abinoote. Ladina keeles on sõnas üldjuhul pärast rõhulist silpi kuni kaks silpi, seega saab ühe rõhulise silbi kohta olla ainult üks abinoot. Joonise 2 transkriptsioonis (1) on olukord, kus lõpetuse esimene aktsent langeb kokku ühesilbilise sõnaga "in". Sellele järgneb sõna "nationibus", milles on rõhk kolmandal silbil. Rõhulisele silbile eelneb kaks rõhutut silpi ja taas on vajadus vaid üheks abinoodiks.

Viienda laadi psalmivormelil on vahepeatuses ühe aktsendiga kadents ja lõpetuses kahe aktsendiga kadents. Laulmiseks peab leidma liigenduskohast kadentsile lähima rõhulise silbi või rõhulised silbid ja viima need kokku kadentsis märgitud domineeriva noodi või domineerivate nootidega. Joonisel 2 on ladina keeles domineerivate nootide peal silbid "Domine", "in" ja "nationibus". Kõik need silbid on võrreldes naabersilpidega tunnetatud pikematena ja sobituvad seetõttu hästi kadentsi domineerivate nootidega. Eesti keeles langeb vahepeatuse esimesele noodile sõna "rahvaste" esimene silp, mis on küll pearõhuline silp, aga mitte selle sõna pikim silp. Rakendades aktsentuaalset kadentsi tekib olukord, kus vormel soodustab sõna "rahvaste" esimese silbi pikendamist, kuigi pikana tajutud silp on hoopis sõna teine silp - "rahvaste". Lõpetuses seda ei probleemi ei esine, sest mõlemas transkriptsioonis langevad kadentsi aktsentidele pikana tunnetatud silbid: (2) "rahvahõimude" ja "keskel" või (3) "rahvahõimude" ja "keskel". 

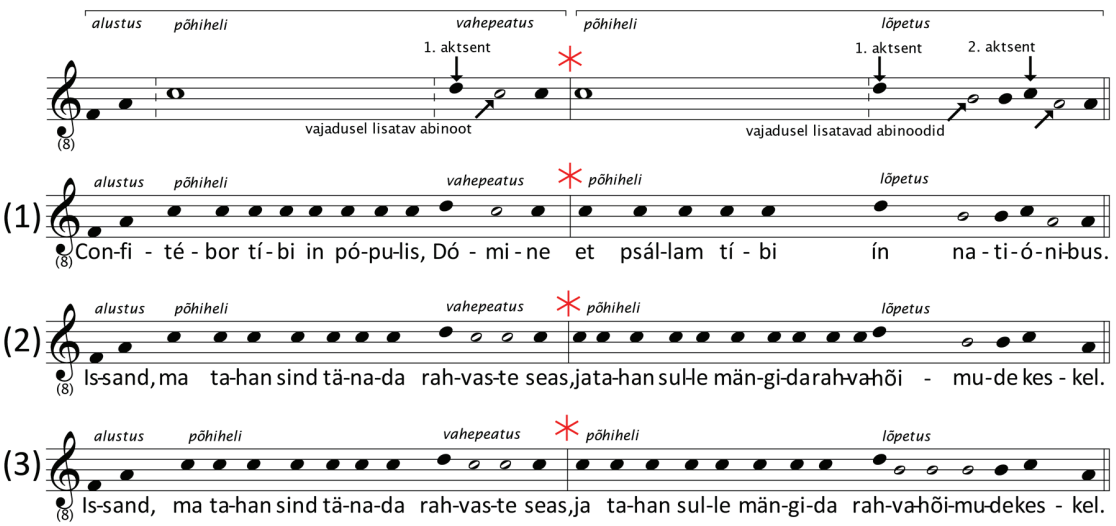

Joonis 2. Näide aktsentuaalsetest kadentsidest ladina ja eesti pühalaulus. Tekst: Ps 108:4 (ladinakeelses Piiblis Ps 107:3); meloodiavormel: viienda laadi aktsentuaalne psalmivormel (Liber 1958: 115). Joonisel on toodud psalmivormel ja kolm transkriptsiooni, kuidas tekst ja vormelis esitatud meloodiline informatsioon kokku viiakse.

See ongi eesti keele prosoodia põhiline eripära, et pearõhuline esimene silp ei pruugi alati olla pikk nt "rahvaste" "alati", "tajuma”, "erinevus". Seega ei ole põhjust otsida kadentsi domineerivaid noote rõhulise silbiga ja kasutada saab märksa universaalsemat printsiipi ehk "kursiivset kadentsi", mis tähendab, et alati loetakse teksti liigenduskohtadest selline arv silpe nagu vahepeatuses või lõpetuses on noote. Vajadust abinootide järgi ei ole.

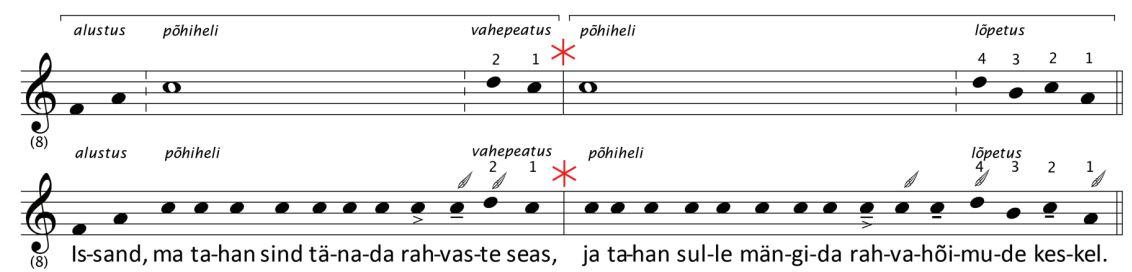

Joonis 3. Näide kursiivsest kadentsist eestikeelses pühalaulus. Tekst: Ps 108:4; meloodiavormel: viienda laadi kursiivne psalmivormel (ELP S56). Tingmärgid transkriptsioonis: \& (sulg)-meeldetuletus silbi rõhutuse kohta; -ja-(lühike või pikk kriips noodi all)-vastavalt väiksem ja suurem pikendus; >- meeldetuletus aktsendi olulisusest. 
Kursiivse kadentsi kasutamine annab ühe printsipiaalselt olulise lisaväärtuse - meloodiavormel ei suuna enam teksti lausumist - kursiivne printsiip sunnib lauljat fokusseerima tekstile ja selle prosoodilisele rütmile. See ju ongi, mida me nii kirikulaulus kui ka muus vokaalmuusikas tahame - keskendumist tekstile. Nootide pikendamine ja rõhutamine kursiivses süsteemis toimub ainult teksti järgi.

On veel üks erinevus ladina ja eesti keele vahel, mis kõneleb kursiivse kadentsi kasuks eestikeelses pühalaulus - kuna pearõhk on alati esimesel silbil, siis võib peale esimest silpi ainuüksi lihtsõnas olla vajadus kahe või enama abinoodi järgi, nt "toredasti", "kaunistustele"; rääkimata siis liitsõnadest, nt "rahvahõimude", kus abinootide vajadus on veelgi suurem. Kui järgida aktsentuaalses süsteemis eestikeelse sõna pearõhku, võib tekkida vajadus paljude abinootide järgi, nt joonis 2 näide (3). Selle tagajärjel venivad kadentsid pikaks, kaotavad oma sujuvuse ja võivad muutuda kohmakaks.

Minupoolne eksklusiivne toetus kursiivsele kadentsile ei tähenda, et aktsentuaalset kadentsi kasutades ei saaks eesti keeles kontemplatiivset pühalaulu laulda. Pigem võiks öelda, et kursiivne kadents on vaieldamatult parim kui rääkida universaalsest eestikeelse kontemplatiivse pühalaulu süsteemist, mis absoluutselt alati rakendub ühetaoliselt. Joonisel 2 on transkriptsioonide (2) ja (3) näitel demonstreeritud, kuidas aktsentuaalne süsteem võib olla ambivalentne - lõpetust võib alustada nii liitsõna "rahvahõimude" esimesest silbist kui kolmandast silbist. Kursiivses süsteemis sellised küsimusi tekkida ei saa. Arvestades, et Piibli proosatekstiline kirikulaul on alles tulemas Eestimaa luterlikku praktikasse, oleks hea, kui kasutatav süsteem oleks universaalne ja kõikidele eesti keeles lauljatele ühtmoodi mõistetav. Aktsentuaalne süsteem on üsnagi keeruline ning ambivalentne ja nõuab iga meloodiavormeli puhul teksti partikulaarset markeerimist. Aktsentuaalne kadents küll lihtsustab märgatavalt laulmist nendes keeltes, kus rõhuline silp on üldjuhul tajutud pika silbina. Eesti keeles ei anna aktsentuaalne printsiip seda lisaväärtust. Pigem vastupidi - see võib moonutada eesti keele prosoodilist rütmi.

Siinkohal on tegemist kontemplatiivse stiili väga spetsiifiliste küsimusega, mille kohta on aastal 2018 plaanis publitseerida eraldi artikkel (Jõks 2018, ilmumas). Ekskursi lõpetuseks julgen väita, et olen eestikeelse pühalaulu didaktikas jõudnud järeldusele - eestikeelses, vormelitel põhinevas kontemplatiivses pühalaulus ei ole otstarbekas kasutada indoeuroopa keeltele omast aktsentuaalset kadentsi ja sobivam on rakendada kursiivse kadentsi põhimõtteid. Aastatepikkune praktika Pühalaulu Koolis on seda järeldust veenvalt kinnitanud. Seepärast on ka järgnevad näited kõik kursiivse kadentsi põhimõttel. Eelpoolviidatud partikulaarne uurimus lahkab detailselt kitsaskohti, mis tekivad aktsentuaalse kadentsi rakendamisel eesti pühalaulus, eriti meloodiavormelites, mis kasutavad keerulisema ülesehitusega kadentse. 


\subsubsection{Kontemplatiivse stiili näited}

Järgnevalt demonstreerin, kuidas kontemplatiivses stiilis kursiivse kadentsi põhimõtteid rakendades erinevad meloodiavormelid tekstiga kokku viiakse. Näited pärinevad raamatu "Eesti laulupsalter" neljandast prooviväljaandest (vt ka ptk 2.2). ELP kolm eraldilehitsetavat sektsiooni omavad separaatset leheküljenummerdust ja värvide järgi, millega numbrid on trükitud, on hakatud neid kutsuma vastavalt "roheline raamat" - antifonaarium; "sinine raamat" tonaarium ja "punane raamat" - psalter.

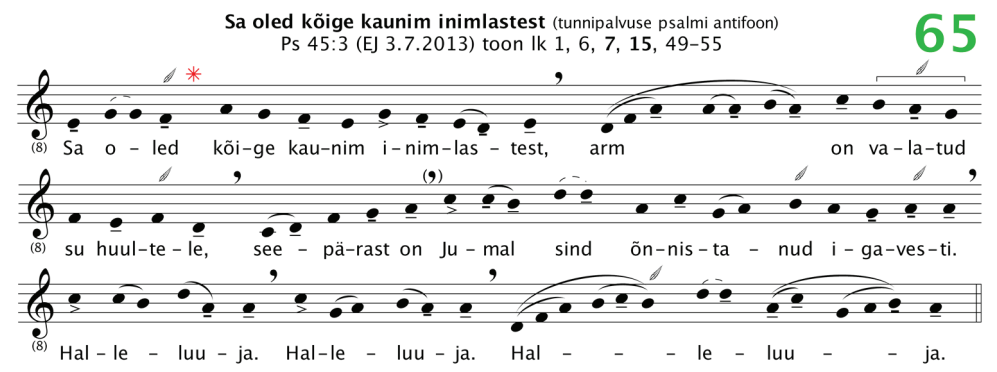

Neljanda laadi psalmitoon (tunnipalvus; VAT, 19. saj. var E1 var 2, toim. EJ)

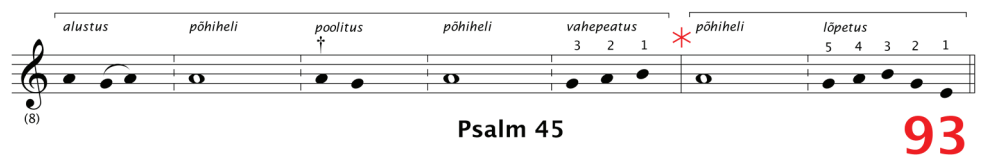

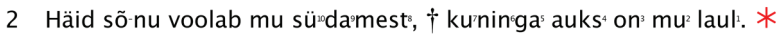

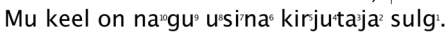

3 Sa oled kõige kaunim inimlastest ${ }^{10}, \uparrow$ arm $^{9}$ on ${ }^{8}$ vałlatud ${ }^{5}$ su $^{4}$ huulstele $e^{1}, *$ seepärast on Ju-mal ${ }^{10}$ sind $^{9}$ õnnnistannud ${ }^{4}{ }^{4}$ gaves $^{2} \mathrm{i}^{1}$.

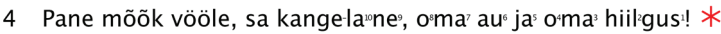

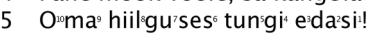

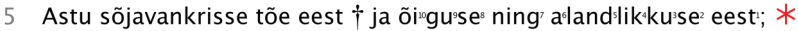

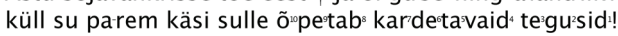

6 Su nooled on te-ra'vad" † rah'vad lan'gevad ${ }^{4}$ su $^{3} \mathrm{al}^{2} \mathrm{a}^{1}$, * nooled tungivad kunin'gas vaen'las'tes sü‘dasmes'se'.

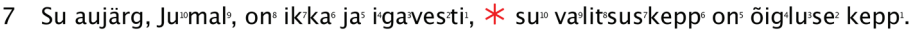

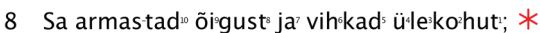

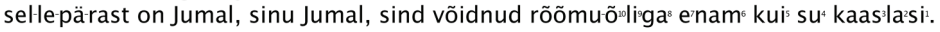

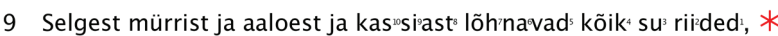

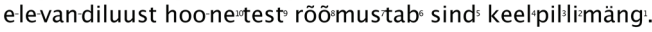

10 Kuningate ${ }^{10}$ tütreid leirdub ${ }^{6}$ sus $^{5}$ kaas4laste $^{2}$ seas: $*$

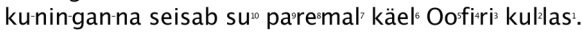

Joonis 4. Näide "Eesti laulupsaltrist" (ELP), nii nagu see laulajale avaneb kui ta soovib laulda Psalmi 45 tooniga 53 ja antifooniga 65 (R65; S53; P93). ELP formaat on A4. Joonisel on vaadet on mõnevõrra optimeeritud -vahesid sektsioonide vahel on ruumi kokkuhoiuks vähendatud. Tingmärgid antifoonis: * - solisti intonatsiooni lõpp ja ühise laulmise algus; (sulg)-meeldetuletus silbi rõhutuse kohta; - ja - (lühike või pikk kriips noodi all) - vastavalt väiksem ja suurem pikendus; >-meeldetuletus aktsendi olulisusest. Antifooni pealkirja all on valik vormelitest ehk toonidest, mida saab selle antifooni puhul kasutada. Psalmitooni pealkirja järel on sulgudes selgitus tooni päritolu kohta ja muu tehniline teave. Psalmil 45 on kokku 18 salmi - psalm jätkub laulupsaltri "punase raamatu” leheküljel 94. 
Joonistel 4-6 on toodud kolm psalmivormeli näidet ja need sisaldavad (1) psalmivormelit; (2) teksti (Ps 45:2) ja (3) transkriptsiooni, kuidas tekst ja vormelis esitatud meloodiline informatsioon kokku viiakse. Transkriptsioonis ei ole rütm noteeritud, vaid see kujuneb prosoodilise rütmi alusel loomuliku lausumise järgi.

Esimeseks näiteks on keskaegne vormel, mis pärineb 10. sajandi käsikirjast "Commemoratio brevis" (Bailey 1979: 47). Tegu on vanima säilinud kirjaliku allikaga, mis toob meieni keskaegsete VT psalmitoonide meloodilise informatsiooni. Selles näites on nii vahepeatuses kui lõpetuses neli silpi. Joonisel 5 kujutatakse VT psalmitooni, mis on eriline oma spetsiifilise modaalse karguse poolest. See tekib "vahepeatuses" laskuva helijärgnevuse "h-a-g-f" tõttu, mille äärmised noodid moodustavad suurendatud kvardi (f-h). Suurendatud kvart või vähendatud kvint ehk tritoon sai järgnevatel sajanditel kuulsa nimetuse diabolus in musica ja selle kasutamist välditi. Kümnenda sajandi allikas on triiton laskuva meloodiakäigu äärmiste helidena selgelt tajutav. Vatikani 19. ja 20. sajandi väljaannetes tritooni sellisel kujul ei leidu. Suurendatud kvart on muudetud puhtaks kvardiks (f-b), ${ }^{21}$ mis loob märksa turvalisema, aga samas isikupäratuma kõla.

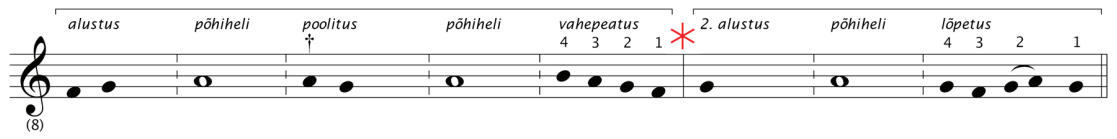

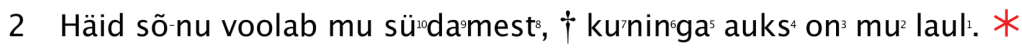

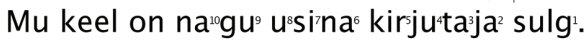

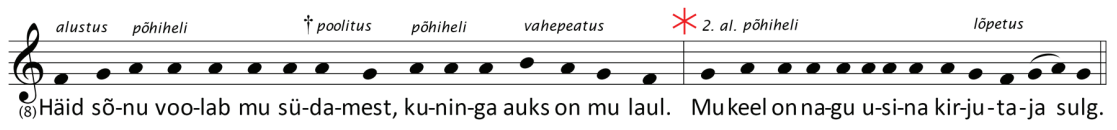

Joonis 5. ELP S1; P93 (Ps 45:2) ja transkriptsioon; keskaegses allikas ei sisaldu poolitust - see on ELP toimetaja lisatud.

Teiseks näiteks (joonis 6) toon ühe oma konstrueeritud pühalaulu meloodiavormelitest, mis imiteerib Kalevala kontekstist tuntud regilaulu meloodiat. Seetõttu on seda tooni hakatud hellitavalt kutsuma "Lennart Meri nimeliseks psalmitooniks". Ka selles toonis on nii vahepeatuses kui lõpetuses neli silpi, aga minoorse regilauluviisi imiteerimine loob täiesti teistsuguse atmosfääri. Selles vormelis on olemas ka üks element, mis eelmises näites puudus - “2. põhiheli”. 


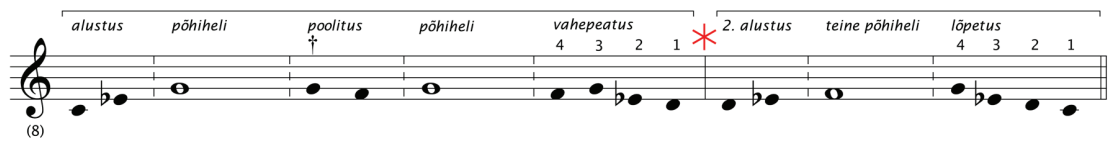

2 Häid sõ-nu voolab mu sürdamest ${ }^{3}, \uparrow$ ku'ninggas auks ${ }^{4}$ on ${ }^{3} u^{2}$ laulı. *

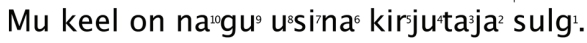

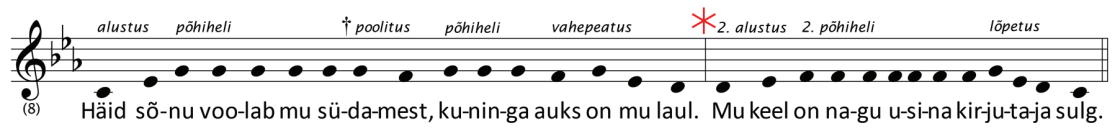

Joonis 6. ELP S84; P93 (Ps 45:2) ja transkriptsioon.

Esimene ja teine näide on mõlemad suhteliselt lihtsad, omades nii vahepeatuses kui ka lõpetuses vaid nelja silpi. Kolmandaks näiteks olen seetõttu valinud enda komponeeritud psalmitooni, mis kasutab ära kõik kümme indekseeritud silpi nii vahepeatuses kui lõpetuses ja annab aimu kontemplatiivse stiili vormelite mitmekülgsetest võimalustest. Kolmandas näites (joonis 7) tekib olukord, kus kümnesilbiline "vahepeatus" haarab endasse ka tekstis asuva poolituse, mis asub seitsmenda ja kaheksanda silbi vahel ning jääb selle vormeli kasutamisel ära.

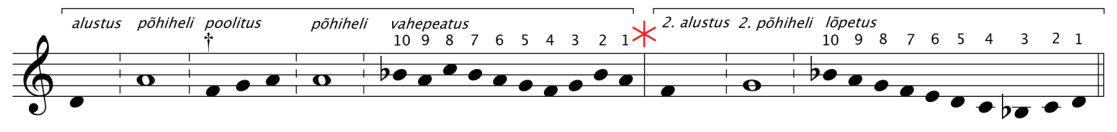

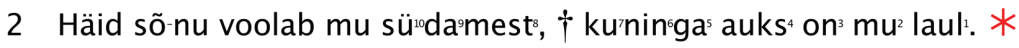

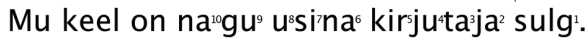

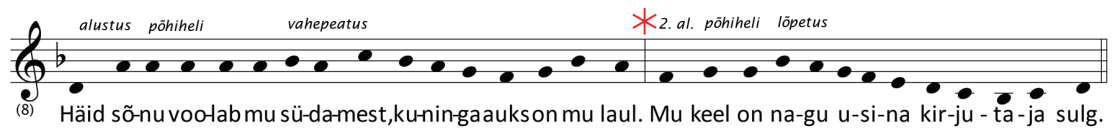

Joonis 7. ELP S120; P93 (Ps 45:2) ja transkriptsioon. 


\subsubsection{Kontemplatiivse stiili kokkuvõte}

Nagu näited demonstreerivad, saab pühalaulu kontemplatiivses stiilis kasutada ära nii (1) keskaegse tarkuse varasema kihistuse, mis näiteks Vatikani 19. ja 20. sajandi väljaannetes on rooma-katoliku kiriku poolt unustatud (joonis 5), kui ka (2) kaasaegse innovatsiooni, võttes arvesse meie kultuuri spetsiifikat, nt regilaulumeloodikat (joonis 6), aga ka (3) helilooja püüdluse originaalsele loomingulisele eneseteostusele (joonis 7). Võimalused laulda Piibli tekste meloodiavormeleid kasutades on vägagi mitmekesised. Ma olen veendunud, et erinevad autorid avastavad selles žanris veel hulgaliselt huvitavaid lahendusi.

Kokkuvõtteks defineerin stiili: kontemplatiivne stiil on seesmiselt vaatlev, mõtisklev, endassesüüviv stiil, mille põhitunnuseks on silpide lausumine valdavalt ühel helikõrgusel ja tulemuse rakendamine erinevate meloodiavormelite alusel. Nõnda ongi loodud esimene sillapuu prosoodia ja meloodia vahel. Teksti lausumisel ilma isikliku prosoodilis-intonatsioonilise tõlgenduseta ehk ühe prosoodia parameetri teadlik "väljalülitamine" tekitab meloodia ehk ühehäälselt väljendatud muusikalise mõtte. Selles meloodias on tegu küll ainult ühe helikõrgusega, aga pangem hästi tähele, et sellest hoolimata vastab see nii Kostabi ja Semleki (1976) kui ka Semleki (2003) meloodia definitsioonile. Asetades saadud meloodia vormelite konteksti, moodustubki pühalaulu kontemplatiivse stiili tervik.

\subsection{Deklaratiivne stiil (avaldav, seletav või ka selgitav)}

Selgitades kontemplatiivset stiili saime eelaimu ka sellest, mis on deklaratiivne stiil. Kui kontemplatiivses stiilis lülitatakse isiklik prosoodilis-intonatsiooniline tõlgendus välja ja alles jääb ühel helikõrgusel "puhas tekst", mida lausutakse meloodiavormelit kasutades, siis deklaratiivses stiilis on olukord vastupidine - personaalset prosoodilis-intonatsioonilist tõlgendust püütakse teksti veendumusega lausumise kaudu võimendada, seda tähelepanelikult kuulata ja sellest meloodiline informatsioon ekstraheerida. Üks põhjapanev erinevus on veel: kui kontemplatiivse stiili esmaseks väljundiks on see, kuidas me koos tekste lausume-laulame ja ühel helikõrgusel lausumine ja vormelite rakendamine sünnib nii-öelda kohapeal ja iga kord uuesti, siis deklaratiivse stiili esmaseks väljundiks on helilooja-poolne meloodiline lahendus, mille ta teksti sisemise veendumusega lausudes oma kõnest ekstraheerib ja fikseerib valitud muusikalise laadi astmetena ning mida seejärel saab koos laulda. Selline kompositsioonivahend sai pühalaulu keelepruugis nimeks "kõnekurvide meetod".

Tähtis on siinkohal rõhutada, et kaks erinevat inimest võivad jõuda seda meetodit rakendades sama teksti puhul erinevate meloodiliste tulemusteni, sest 
nende veendumused, mis kajastuvad prosoodilistes parameetrites, on erinevad. Väga palju loeb ka see, kui laiaks määratleb helilooja meloodilise informatsiooni mõõtkava - kas kasutatakse tertsi, kvinti, oktavit või veel suuremat ulatust. Oluliseks faktoriks on muusikalise laadi valik, nt kas loomulik minoor või täistoonlaad - tulemus on täiesti erinev. Aga jäädes truuks sellele meetodile jõutakse suure tõenäosusega tulemuseni, millel on sisemine prosoodiline loogika ja mis on seetõttu inimestele lauldes omane ja suupärane.

Kontemplatiivset stiili käsitledes kirjutasin ühel helikõrgusel lausumise fenomeni lokaliseerimisest kui "siiamaani kõige hämmastavamast ahaa-elamusest minu pühalaulualases tegevuses". Ka deklaratiivses stiilis on selline aspekt olemas. Töö käigus avastasin oma suureks hämmastuseks, kui tõhusalt on kõnekurvide meetod kooskõlas Joppichi hüpoteesiga. Joppichit parafraseerides võin öelda, et emakeelne deklaratiivne pühalaul on minu jaoks elumuutvate sõnade usu ja veendumusega lausumine, nii et nendes peituv meloodiline informatsioon saab ilmsiks reprodutseeritava muusikana.

\subsubsection{Deklaratiivse stiili näited kõnekurvide meetodi rakendamisel}

Järgnevas demonstratsioonis on katsetekstiks Ps 139 esimene salm "Issand, Sa uurid mind läbi ja tunned mind”. Joonis 8 abil käime samm-sammult läbi kõnekurvide meetodi nii nagu ma seda ise igapäevaselt kasutan, vaagides erinevaid võimalusi, mida meetod pakub. Ka siin on tegemist foneetilise eksperimendiga, mida igaüks saab iseseisvalt korrata ja selle tulemuslikkuses veenduda.

(1) Kõnekurvide meetod algab alati teksti häälega lausumisest ja sellesse süvenemisest - mida see tekst mulle tähendab, mida see tekst mulle ütleb? Lausumist tuleks teha kümneid ja kümneid kordi järjest, silpe aina intensiivsemalt kokku sidudes. Iga lausumise korraga muutub meloodiline informatsioon reljeefsemaks. (2) Seejärel tuleb määrata mõtteline kesktelg ehk "nullpunkt" pannes tähele, millised silbid on nullpunktis, millised on pigem ülevalpool ja millised allpool. (3) Nõnda saab iga silp esialgu väärtuseks +, 0 või -, millest moodustub öeldud teksti kood - minu poolt öelduna on see: “ $++0+0-+0-0$ - -”. Järgmiseks peab fikseerima kõrgeima ja madalaima intonatsiooniga silbi. (4) Selle lause puhul on minu tunnetuses esimene silp kõrgeim ja viimane madalaim. Põhimõtteliselt on meil nüüd olemas piisav teave, et konstrueerida meloodia. (5) Esimeses meloodias on diatoonilisel helireal keskteljeks f noot. Aga see ei pruugi nii olla - (6) teksti koodi saab rakendada ka nõnda, et keskteljeks on näiteks fis noot. See tähendab, et pooltoon ei ole enam 0 ja - vahel vaid + ja 0 vahel. (7) Samuti võib koodi rakendada nii, et pooltooni üldse ei ole - keskteljeks jääb siis f noot, aga alumist astet (-) madaldatakse poole tooni võrra. 
(1) Is- sand, Sa uu- rid mind lä- bi ja tun- ned mind.

$\begin{array}{ccccc}0 & 0 & 0 & 0 \\ \text { (2) Is- sand, Sa } & \text { uu- rid } & \text { mind lä- } & \text { bi } & \text { ja tun- ned mind. }\end{array}$

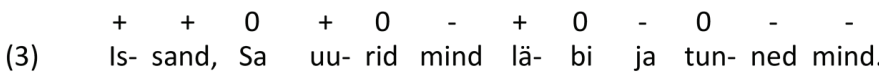

(4) kõrgeim madalaim
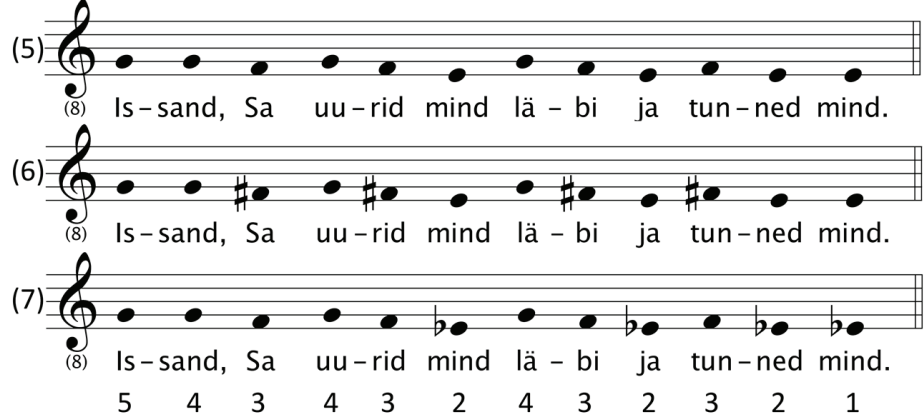

(8) Is- sand, Sa uu- rid mind lä- bi ja tun- ned mind.
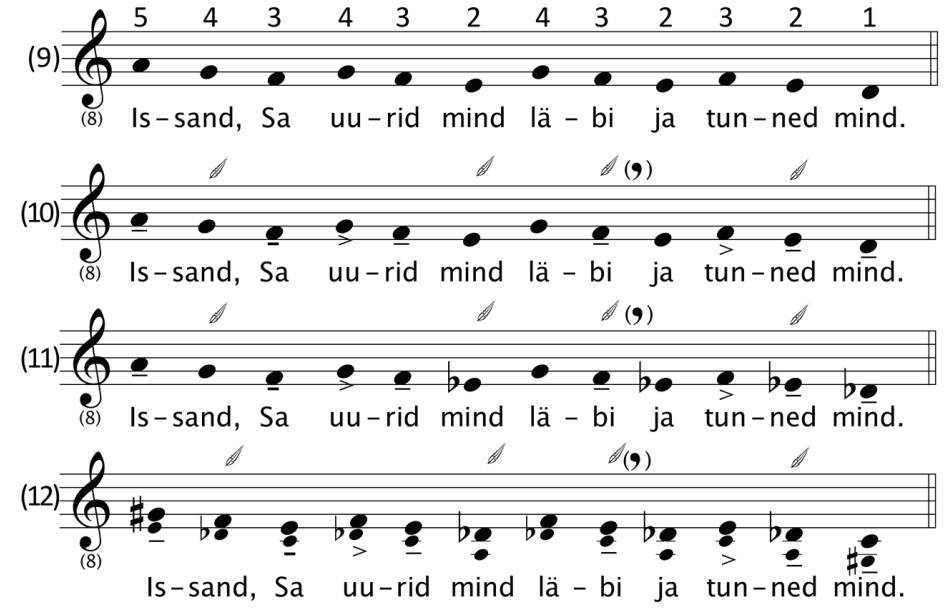

Joonis 8. Kõnekurvide meetodi rakendamine tekstile "Issand, Sa uurid mind läbi ja tunned mind" (Ps 139:1). Tingmärgid: \& (sulg) - meeldetuletus silbi rõhutuse kohta; - ja - (lühike või pikk kriips noodi all) - vastavalt väiksem ja suurem pikendus; >-meeldetuletus aktsendi olulisusest; (,) -vajadusel kasutatav hingamispaus.

Kõik need kolm meloodiat vastavad lause koodile, meloodia (5) on früügia laadi (või 3. kirikulaadi) tunnetusega, meloodia (6) on minooritunnetusega (või 1. kirikulaadi tunnetusega) ja meloodia (7) on mažooritunnetusega (või 5 . või 7. kirikulaadi tunnetusega). 
Järgmises etapis võib muuta teljestiku tihedamaks, lisades täiendavaid telgi nullpunkti ja kõrgeima silbi ning nullpunkti ja madalaima silbi vahele. Siinkohal tuleb teha otsus, millist ulatust komponeeritavale palale soovitakse. Et jääda demonstratsioonis suhteliselt vaoshoituks, võtan selleks ulatuseks kvindi. Kui aga helilooja otsustaks kvindist laiema ulatuse kasuks, tuleks süllaabiliselt stiililt lülituda neumalisele stiilile või loobuda astmelisest liikumisest. (8) Kui ulatuseks on kvint, siis lisandub kaks telge. Nullpunkti väärtuseks on nüüd 3 ja nullpunkti mõlemale poole on tekkinud kaks telge: 5 ja 4 üles ning 2 ja 1 alla. Nüüd tuleb taas intonatsiooni järgi otsustada, millised + väärtused on 5 ja millised 4 ning millised - väärtused on 2 ja millised 1. (9) Mina lõpetan meloodilise informatsiooni ekstraheerimise eksperimendi diatoonilise helireaga, mille keskteljeks on f noot (väärtus 3). Saadud minooritunnetusega (või 1. kirikulaadi tunnetusega) meloodia järgib üllatavalt hästi teksti lausumisel tekkivat prosoodilist meloodiakontuuri.

Üks prosoodia parameeter - intonatsioon - on nüüd fikseeritud ja jääb üle lisada ülejäänud kaks parameetrit temporaalne ja dünaamiline. Taas teksti lausudes tuleb endale teadvustada, millised on pikana ja millised lühikesena tunnetatud silbid ning millised on rõhulised ja millised rõhutud silbid. (10) Kriips noodi all pikendab nooti (kasutusel on lühike ja pikk kriips, vastavalt väiksem ja suurem pikendus); suleke noodi peal tuletab meelde, et tegu on rõhutu silbiga, rõhumärk tuletab vajadusel meelde aktsendi olulisust. Juba etteruttavalt on siinkohal tegu mõningase vaba stiili mõjuga - noot, mis vastab sõnale "Sa", on varustatud lühikese allkriipsuga. Seda mitte seetõttu, et prosoodilises rütmis see sõna pikana tunduks. Pigem on just tegu üsnagi lühikese ühesilbilise sõnaga. Kuna aga tegemist on isikulise asesõnaga Jumala kohta, siis on "Sa" sõna kergelt markeeritud, et sellest mitte liiga pealiskaudselt üle libiseda. Viimase noodi all olev pikendus on pala lõpus toimuva aeglustuse tarvis.

Sama meloodiline informatsioon võib aga kõlada ka mõnes eksootilisemas laadis, nt (11) täistoonlaadis või (12) pooltoon-poolteisttoon-laadis, mis on tuntud setu mitmehäälsest laulutraditsioonist. Selliste laadide kasutamine lisab põnevat värskust kirikulaulu, samas kui prosoodiline loogika endiselt säilib. Ei ole ka keelatud oma heliridade konstrueerimine ja nende rakendamine. Taas võib tõdeda, et võimaluste palett on vägagi lai.

\subsubsection{Deklaratiivse stiili kokkuvõte}

Deklaratiivne stiil, mis on aluseks nn kõnekurvide meetodile on hämmastavalt adekvaatne kompositsioonitööriist kui soovitakse võrdlemisi lihtsat ja loogilist loomulikule prosoodilisele intonatsioonile vastavat meloodiat. Kasutan kõnekurvide meetodit ise iganädalaselt ELP viiside komponeerimisel. Kõnekurvide 
meetodi abil õnnestus luua ka teine sillapuu prosoodiast meloodiani. Kokkuvõtteks defineerin stiili: deklaratiivne stiil on avaldav, seletav või ka selgitav stiil, mille tunnuseks on meloodia, mis püüab järgida teksti lausumisest tekkivat helikontuuri. Stiil on "seletav ja selgitav" seetõttu, et oma prosoodilisintonatsioonilise tõlgenduse kaudu annab helilooja kasutatud tekstile teatava omapoolse seletuse.

\subsection{Vaba stiil}

\subsubsection{Deklaratiivses stiilis pühalaulu antifooni muusikaline}

\section{täiendamine}

Nagu stiili nimigi ütleb, võib vabas stiilis meloodia sündida mistahes meetodit kasutades. Praeguse demonstratsiooni raames on aga eelkõige tegu deklaratiivses stiilis meloodia täiendamisega - saadud meloodiale lisatakse emotsionaalne ja/või konstruktiivne heliloominguline komponent. See tähendab järeleandmiste tegemist kõnekurvides või neist täiesti loobumist, et muuta meloodiat oma loomingulise nägemuse kohaselt efektsemaks. Selleks võib kasutada nt neumaatilise ja/või melismaatilise stiiliga "mängimist" ja/või alteratsioonide lisamist. Demonstratsiooniks võtan joonise 8 rea (10).

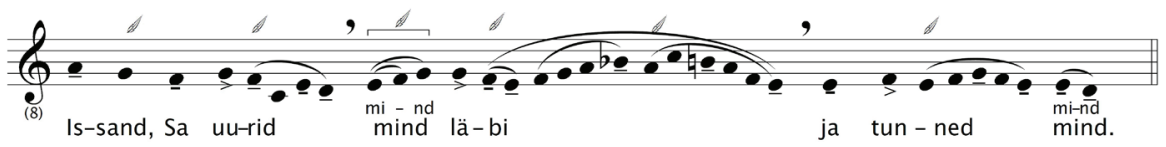

Joonis 9. Vabas stiilis pühalaulu antifoon, mille aluseks on võetud deklaratiivses stiili komponeeritud pühalaulu antifoon (vt joonis 8 viis (10). Tingmärgid: d (sulg) - meeldetuletus silbi rõhutuse kohta; - ja-(lühike või pikk kriips noodi all) - vastavalt väiksem ja suurem pikendus; > - meeldetuletus aktsendi olulisusest; , - hingamispaus.

Niisiis võtsin (joonis 9) kasutusele sõnade "uurid, läbi, tunned" pikana tunnetatud teised silbid ja lisasin muusikalist materjali; sõnades "mind" kasutasin võimalust noteerida eraldi välja heliline kaashäälik n. Sõnad "uurid ja tunned" said neumalise lisanduse; sõna "läbi" sai melismaatilise lisanduse ja alteratsiooni.

Koos vaba stiili rakendamisega muutus artikulatsioon, agoogika ja fraseerimine. Lisada tuli kaks hingamispausi. Muusikaliselt läks lugu ehk põnevamaks, aga kas tekst sellest võitis, pole päris kindel. 


\subsubsection{Vaba stiili kokkuvõte}

Enamik minu komponeeritud pühalaulu antifoone ja responsooriumeid on deklaratiivses stiilis koos vaba stiili sugemetega. Selle üheks näiteks on ka antifoon "Sa oled kõige kaunim inimlastest" (vt joonis 4; ELP R65). Kui deklaratiivne stiil pakkus laia valikuskaalat, siis vaba stiili puhul on võimalused peaaegu piiramatud ja sõltuvad suurel määral helilooja leidlikkusest. Hea oleks kui vaba stiili kasutamise juures oleks aga leidlikkus tasakaalus aukartusega kasutatava teksti ees, et keskseks jääks siiski Piibli sõnad, nende mõtestamine ja edasi andmine. Kokkuvõtteks defineerin stiili: vaba stiili põhitunnuseks on helilooja teadlik valik mitte arvestada keele prosoodilisi parameetreid ja eelistada oma loomingulist tunnetust meloodilise materjali kujundamisel.

\section{Kokkuvõte}

Eesti kirikulaulu-alases tegevuses ei ole seni Piibli proosatekstilise kirikulaulu ehk pühalaulu metodoloogiat kirjeldatud. Käesolev katse on esimene ja leiab loodetavasti edasiarendamist edasises diskussioonis ja kirjutistes. Artiklis esitatud metodoloogia näitas, et sihipärane keskendumine eesti keele prosoodiale avab mitmeid uusi võimalusi eestikeelses kirikulaulus. Kõik kolm pühalaulu stiili (1) kontemplatiivne, (2) deklaratiivne ja (3) vaba stiil loovad põnevaid tekstuaalseid ja muusikalisi väljakutseid ning loovad võimalusi kirikulaulu repertuaari rikastamiseks. Kontemplatiivse ja deklaratiivse stiili abil on õnnestunud luua arusaadav sild (eesti keele) prosoodia ja meloodia vahel. Seetõttu võib lõppjäreldusena öelda, et eesti keele prosoodia parameetritega arvestamine saab kaasa aidata eesti keelele omase kirikulaulu tulemuslikule loomisele ja viljelemisele. Pühalaul vääristab meie emakeele kõla, tunnustab traditsiooni, millest meie muusikakultuur võrsub ja toob esile meie kirjakeele ja meie kultuuri tüviteksti - Piibli.

\subsection{Järgmised sammud}

Pühalaulu-alasel tegevusel on minu tegevuses olnud kaks suunda, mis teineteisega põimudes, vastastikku teineteist täiendades ja vahel ka segades, edasi kulgevad. (1) Üks neist on kognitiivse muusikateaduse, muusikaajaloo ja hümnoloogia ning liturgiateoloogia valdkondades toimuv teadustöö ja (2) teine on heliloominguline ja pedagoogiline kirikulaulu-alane tegevus. Edasistes sammudes oleks vaja arendada mõlemat suunda võrdse kaaluga. Teadussuunal tuleks 
alustada (1) kontemplatiivse stiili kirjeldamise ja analüüsimisega kognitiivse muusikateaduse kontekstis; (2) samuti oleks vaja läbi viia ammuplaneeritud kõnekurvide meetodi vaatlemine tajukatse kaudu. See tajukatse võiks meile anda uut teavet eesti keelemuusika kohta, sh tuua esile võimalikke universaale Piibli tekstide lausumise intonatsioonides. Loomingulises plaanis tuleb (1) kindlasti lõpule viia "Eesti laulupsaltri" projekt, mis loodetavasti juhtub 2020. aastaks ja (2) seejärel alustada pühalaulu õpiku kirjutamist.

\section{Tänusõnad}

Artikkel on valminud riikliku programmi "Eesti keel ja kultuurimälu" (projekt EKKM14-335) ning Eesti Kultuurkapitali toetusel.

Projekti "Eesti laulupsalter ja pühalaul” teised toetajad on Eesti Kirikute Nõukogu, Siseministeerium, Pühalaulu Kool, Liturgilise Muusika Ühing Scandicus, EELK Tallinna Toompea Kaarli Kogudus, Eesti Piibliselts, Kaheksa Sajandit Maarjamaad Koostöökogu, Reformatsioon 500 ümarlaud.

Artiklis on kasutatud materjali ettekandest "Prosoodia rollist kujunevas eestikeelses ühehäälses a cappella kirikulaulus ehk pühalaulus", mille pidasin 16. rakenduslingvistika kevadkonverentsi 2017 sektsioonis "Kõne ja muusika" 21. aprillil 2017 Eesti Keele Instituudis.

\section{Lühendid}

ELP - Eesti laulupsalter

EELK - Eesti Evangeelne Luterlik Kirik

KSLM - keskaegne sakraalne ladina monoodia

P - ELP punane raamat ehk psalter

PPK - Piibli proosatekstiline kirikulaul; sünonüüm on pühalaul

$\mathrm{R}$ - ELP roheline raamat ehk antifonaarium

$\mathrm{S}$ - ELP sinine raamat ehk tonaarium

UT - Uus Testament

VT - Vana Testament 


\section{Kommentaarid}

1 Ülo Vooglaiu järgi on metodoloogia "filosoofiline õpetus printsiipide süsteemist, mille kohaselt tegutsedes oleks väljavaateid usaldatavate tulemusteni jõudmiseks." Vt https:// www.tlu.ee/opmat/ka/opiobjekt/Kasvatusfilosoofilised_paradigmad/metodoloogia_ metoodika_meetod.html (vaadatud 14.10.2017). Käesoleva artikli kontekstis võiks "usaldatavad tulemused" tähendada tulemusliku seose loomist eesti keele prosoodia ja pühalaulu meloodiate vahel nii kontemplatiivses kui ka deklaratiivses stiilis.

${ }^{2}$ Kirikumuusika kontekstis on väga palju viidatud kõigi aegade esimesele kirikulaulu taksonoomiale, Püha Pauluse kuulsale lausele esimesest aastasajast, milles on ka hümnil oma koht: "Kristuse sõna elagu rikkalikult teie seas, kõiges tarkuses õpetage ja manitsege üksteist psalmide, hümnide ja vaimulike lauludega, laulge kogu südamest tänulikult Jumalale!” Kl 3:16.

3 Eesti keeles on sellele kõige lähemal Vello Salo tõlked (vt Salo \& Hirv 2009). Salo ja Hirv ei ole psalme tõlkinud hümnilikult - igale salmile ei saa rakendada sama viisi. Mõningaid püüdeid psalme hümnina ehk koraalina edasi anda leidub ka eesti keeles (vt nt KLPR 1991: laul 364, VT 23. psalmi järele Ivar Rammo). Sarnaseid värsstekstilisi psalmitõlkeid ehk meetrilisi psalmitõlkeid on paljudes keeltes. Neist tuntumad on prantsuskeelne Genfi psalter ehk hugenottide psalter (1533-1543) aga ka vend Martin Lutheri saksakeelsed psalmitõlked.

4 Uues Testamendis (UT) on mitmeid viiteid, kus Naatsareti Jeesus pöördub Jumala poole kasutades Vana Testamendi (VT) psalme. Neist tuntuim on ilmselt Jeesuse surmaeelsed sõnad ristil: "Ja kella kolme ajal kisendas Jeesus valju häälega: "Eloii, Eloii, lemaa sabahtani?"” - see on tõlgitult: "Mu Jumal, mu Jumal, miks sa mu maha jätsid?" (Mk 15:34). Nimetatud salmi juures on viide Ps 22:2 "Mu Jumal, mu Jumal, miks sa mu maha jätsid? Kaugel mu päästest on mu oigamissõnad" (vt Piibel, UT 67, VT 574).

5 EELK konsistoorium kinnitas lähteülesande 7. juunil 2016 ja EELK piiskoplik nõukogu kiitis selle heaks 18. oktoobril 2016.

${ }^{6}$ Proosatekstilise kirikulaulu kohta luterlikes kirikutes vt täpsemalt Jõks 2017.

7 Keskaegne sakraalne ladina monoodia on teaduskeelne nimetus nähtusele, mida eesti keeles kutsutakse ka mõistega "gregooriuse laul". Problemaatikast selle mõiste kohta vt Jõks 2010: 33-52.

8 Meloodia kohta võib leida vägagi erinevaid määratlusi, millest mõned võivad olla üsna eksitavad, nt "viis, kaunikõlaline helide järjestus, mis sisulisest seosest olevaist helidest moodustab terviku" (Vääri et al. 2000: 625). Definitsioonis sisalduvad subjektiivsed ja ambivalentsed hinnangud, nagu "kaunikõlaline", "sisuline seos", "tervik".

9 Arutelu selle kohta vt minu peatselt ilmuvas artiklis "Proosast värsini ja tagasi pühalaulu apoloogia".

${ }^{10}$ Seoses reformatsiooni 500. aastapäevaga korraldasid Rooma-Katoliku Kirik ja Eesti Evangeelne Luterlik Kirik kolmapäeval, 27. septembril 2017 ühiskonverentsi "Konfliktist osaduseni". Lisaks ettekannetele esitleti konverentsil ka raamatu "Konfliktist osaduseni” eestikeelset tõlget. Päev lõppes ühispalvusega Kaarli kirikus, kus loeti muuhulgas ette viis imperatiivi, millega luterlased ja rooma-katoliiklased võtavad endale kohustuse loobuda vastandumisest ja otsida edaspidi vastastikust ühtsust. Vthttp://www.eelk.ee/et/uudised/konverentsi-konfliktist-osaduseni-dokumentja-ettekanded/ (vaadatud 16.10.2017). 
11 Jh 1:1-5; 1: Alguses oli Sõna ja Sõna oli Jumala juures ja Sõna oli Jumal. Seesama oli alguses Jumala juures. Kõik on tekkinud tema läbi ja ilma temata ei ole tekkinud midagi. Mis on tekkinud tema kaudu, oli elu, ja elu oli inimeste valgus. Ja valgus paistab pimeduses, ja pimedus ei ole seda omaks võtnud.

${ }^{12}$ We should ask 'What was the origin of Gregorian chant?' Is it possible that one musician came to a monastery of Frankish monks in the 8th century and said: 'You have so bad a manner of pronouncing your words. Give me all your texts and I will compose a very nice melody and then you can sing.' We must ask, can the origin of Gregorian chant be estetica musicale - a cultivated manner of music of the 8th century?

Monks knew all the texts by heart by rumination. We know that monks knew all the 150 psalms and the New Testament by heart. They did not know it through reading they had no books. They learned it because elder monk pronounced it to them and said: [Godehard is reciting by heart the beginning of the Gospel of St John in Latin] [...].

For hundreds of years, monks learned all the texts this way only. The elder monk pronounced it to them and he did not pronounce only the words - he pronounced his faith and not the faith from the point of view of his subjective understanding. He pronounced what he had heard from another elderly monk, who had heard it from another. Nobody dared to change even a little nuance in it because if you change the sound you also change the sense. Today we cannot print a book with holy texts without having a thorough editing and proofreading. There cannot be allowed any error in the printed text and you most certainly cannot change the text. In the same way, mistakes in sound in early times were not allowed and nor were changes. It was not possible that a composer came and said I have written you ... [Godehard sings the intonation of the introit of the First Sunday of Advent Ad te levavi]. This sound had already existed for hundreds of years. It existed in the sound of the words. For me, Gregorian chant is nothing more than putting this sound that exists in the words at a convenient height of the voice. Monks could do it together - they found a way of a convenient melody that corresponded to the words they learned. When I pronounced to you the beginning of St John's Gospel, I said it this way for your recording, but when the elder monk pronounced it to his novices, he said more. [Godehard recites again the first verses of Gospel of St John, but this time much louder and with certain educational intention.]

If you believe that you have the Evangelium - a New Covenant - you will pronounce in a latter way. For us it is no Evangelium any more. All these words have no sound for us because we have too little faith to give sound enough. You need more faith to pronounce the words in the way that they should be pronounced. Gregorian chant is for me the convenient height of pronouncing the words that change your life, not just only give you some information. (Jõks 2009: 398-399)

${ }^{13}$ Eerik Jõks, "Eesti laulupsalter" (prooviväljaanne 4). Tallinn: Superare Signum, 2013. Kuna ELP ei ole veel trükist ilmunud, siis seda avalikes raamatukogudes enamasti ei leidu. Huvilised saavad materjaliga tutvuda nt Eesti Muusika- ja Teatriakadeemia raamatukogus, aga ka Pühalaulu Koolis ning internetis (http://psalmus.eu/laulupsalter/ palvuste\%20tervikkorrad\%20ja\%20muu/ - 20. november 2017).

${ }^{14}$ Püha Benedictuse reegli (6. sajand) järgi lauldakse monastilises pühalaulu praktikas ühe nädala jooksul läbi kogu VT psalmide raamat. Kui öelda, et tegu on 150 psalmiga, siis ei anna see head ettekujutust materjali mahust. Rääkides aga lehekülgedest, siis viimatiilmunud eestikeelses piiblitõlkes võtab see materjal enda alla leheküljed 563-654 ehk 91 lehekülge. Selleks, et kogu see materjal kloostrielu põhireeglit ora et labora (palveta ja tööta) järgides nädala jooksul läbi lausuda, koguneb monastiline pere kaheksa korda ööpäevas, et lausuda VT psalme. 
${ }^{15}$ On olemas ka selline vormel, mille järgi lausutakse kogu materjal ühel noodil. Seda nimetatakse laulmiseks recto tono (vt nt "Eesti laulupsalter" S151).

${ }^{16}$ Lk 1:46b-55.

${ }^{17}$ Pühalaulu Kooli kohta vt www.psalmus.eu (vaadatud 20. november 2017).

${ }^{18}$ Aktsentuaalse ja kursiivse kadentsi kohta vt Bailey 1976.

${ }^{19}$ Neist tuntuim on vaieldamatult Liber usualis, mille esmatrükk ilmus 1895 ja millest on tehtud väga mitmeid kordustrükke. Tekstikorpus on loomulikult ladinakeelne, aga ilmunud on erinevates keeltes kommentaaridega variante.

${ }^{20}$ Enamik näidetest, kus selliseid vormeleid eesti keeles kasutatakse, on koolitusmaterjalid või mõne koori paljundusmaterjalid ning ringlevad fotokoopiatena ja/või elektrooniliste koopiatena ainult kasutajate ringis. Siiski on olemas ka näited ühes EELK ametlikus, publitseeritud liturgiaraamatus: vt "Kirikukäsiraamat ehk agenda I. Jumalateenistuste käsiraamat" (Agenda 2009). Lk 472-474 on Maarja kiituslaulu jaoks kasutatud 5. laadi meloodiavormelit (vrd Liber 1958: 115, 210); lk 475-477 on Maarja kiituslaulu jaoks kasutatud 4. laadi meloodiavormelit (vrd ibid.); lk 485-486 on Siimeoni kiituslaulu jaoks kasutatud 6. laadi psalmivormelit (vrd ibid. 116, 211).

${ }^{21} \mathrm{Vt}$ nt tonus peregrinus (Liber 1958: 117).

\section{Kirjandus}

Agenda 2009 = Kirikukäsiraamat ehk agenda I. Jumalateenistuste käsiraamat. Tallinn: Eesti Evangeelne Luterlik Kirik.

Apel, Willi 1958. Gregorian chant. Bloomington: Indiana University Press.

Baier \& Tüüring 1994 = Evangelisches Gesangbuch - Ausgabe für die EvangelischLutherischen Kirchen in Bayern und Thüringen. München, Weimar: Evangelischer Presseverb. (Bayern), Wartburg Verl. (Thüringen).

Bailey, Terence 1976. Accentual and Cursive Cadences in Gregorian Psalmody. Journal of the American Musicological Society 29 (3), lk 463-471 (doi: 10.2307/830970).

Bailey, Terence 1979. Commemoratio Brevis De Tonis Et Psalmis Modulandis. Ottawa, Canada: University of Ottawa Press.

Gontier, Augustin-Mathurin 1859. Méthode raisonnée de plain-chant, etc. Paris, Le Mans.

Hiley, David 1993. Western plainchant: a handbook. Oxford: Clarendon Press (https:// epub.uni-regensburg.de/25558/1/ubr12760_ocr.pdf - 21. november 2017).

Häkkinen, Kaisa 2007. Keeleteaduse alused. Tallinn: Eesti Keele Sihtasutus.

Jõks, Eerik 2009. Interview with Professor Godehard Joppich in Frankfurt 2005. Jõks, Eerik. Contemporary understanding of Gregorian chant-conceptualisation and practice Vol 2: University of York, lk 395-404 (http://etheses.whiterose.ac.uk/949/ - 21. november 2017).

Jõks, Eerik 2010. Gregooriuse laulu määratlemine mõiste ja nähtusena ning interpretatsioonilised eelistused tänapäevase praktiseerija vaatenurgast. Res Musica 2, lk 33-52 (http://www.muusikateadus.ee/wp-content/uploads/Eerik-Joks. pdf - 21. november 2017). 
Jõks, Eerik (koost) 2013. Eesti laulupsalter (prooviväljaanne 4). Tallinn: Superare Signum.

Jõks, Eerik 2014. Keskaegne sakraalne ladina monoodia ja selle tänapäevane kõlapilt normaalne tervik või Siiami kaksikud? Res Musica 6, lk 144-185 (http://www. muusikateadus.ee/wp-content/uploads/2014/11/RM6_J\%C3\%B5ks.pdf - 21. november 2017).

Jõks, Eerik 2017 [ilmumas]. Proosast värsini ja tagasi - pühalaulu apoloogia. Rohtmets, Priit \& Remmel, Atko (toim). Eesti Evangeelne Luterlik Kirik 100. EELK UI toimetised. Tallinn, Tartu: EELK Usuteaduse Instituut, Tartu Ülikool.

Jõks, Eerik 2018 [ilmumas]. Ladina psalmivormelite aktsentuaalse ja kursiivse kadentsi problemaatika eesti keele kontekstis.

KLPR 1991 = Kiriku laulu- ja palveraamat. Tallinn: EELK Konsistooriumi kirjastus- ja infoosakond.

Kostabi, Heino \& Semlek, Leo (koost) 1976. Muusika elementaarteooria. Õppevahend. Tallinn: Eesti NSV Kõrgema ja Kesk-erihariduse Ministeerium.

Liber 1958 = Liber usualis Missae et officii pro dominicis et festis cum canto Gregoriano ex editione Vaticana adamussim excerpto et rhythmicis signis in subsidium cantorum a Solesmensibus monachis diligenter ornato. Parisiis, Tornaci, Roma, Neo Eboraci: Desclee \& Socii.

Läti 2015 = Latvijas Evangéēliski Luteriskās Baznīcas Dziesmu Grāmata. Riga: Latvijas Evaṇgēeliski Luteriskās Baznīcas.

Piibel 1999 = Piibel. Vana Testament, apokrü̈̈fd, Uus Testament . Tallinn: Eesti Piibliselts.

Salo, Vello \& Hirv, Indrek (tlk) 2009. Psalmid. Pirita: Maarjamaa.

Saulnier, Dom Daniel 2010. Gregorian chant: a guide. Church Music Association of America (https://media.musicasacra.com/books/gregorian_chant_guide_saulnier.pdf 21. november 2017).

Semlek, Leo 2003. Muusika elementaarteooria õpik. Tallinn: Kodutrükk.

Siitan, Toomas 1989. Keskaja muusika aastani 1300. Õppevahend. Tallinn: Eesti NSV Riiklik Hariduskomitee, teaduslik-metoodiline kabinet.

Särg, Taive 2005. Eesti keele prosoodia ning teksti ja viisi seosed regilaulus. Dissertationes folkloristicae Universitatis Tartuensis 6. Tartu: Tartu Ülikooli Kirjastus (http://www. utlib.ee/ekollekt/diss/dok/2005/b17338311/sarg.pdf - 28. november 2017).

Teder, Tauno \& Lääs, Kadri (toim) 2017. Konfliktist osaduseni. Luterlaste ja katoliiklaste ühine reformatsiooni aastapäev aastal 2017. Luterlaste ja roomakatoliiklaste ühtsuse komisjoni raport. (Tõlkinud Vallo Ehasalu.) Tallinn: Eesti Evangeelne Luterlik Kirik ja Rooma-Katoliku Kirik Eestis.

Vääri, Eduard \& Kleis, Richard \& Silvet, Johannes 2000. Võõrsõnade leksikon, 6. trükk. Tallinn: Valgus. 


\title{
Summary
}

\section{From prosody to melody: Methodology of Estonian scripture prose text based monodic a cappella chant or Estonian sacred plainchant}

\author{
Eerik Jõks \\ Lecturer and Research Fellow \\ Estonian Academy of Music and Theatre \\ eerik@ekn.ee
}

Keywords: Bible, church music, Gregorian chant, Holy Scriptures, liturgical chant, medieval sacred Latin monody, plainchant, prosody, psalm, vernacular

The most widespread Estonian Christian chant is Lutheran chorale, which is based on a text of strophic verses, in which all verses can be sung with the same tune. The roots of the written tradition of the Western Christian chant (9th-10th cc.), however, are in the prose text of the Latin Bible. Nowadays a chanted vernacular prose text from the Bible or vernacular plainchant has found its way to the Lutheran repertoire. The article demonstrates how consideration of the parameters of Estonian prosody can contribute to the creation and practice of Estonian plainchant. In other words, the article describes a system of principles following which the stylistically versatile Estonian plainchant is created. The styles of vernacular plainchant are: (1) contemplative, (2) declarative, and (3) free style.

The Estonian or vernacular plainchant can be defined either through the categories of linguistics or those of Christian piety. In terms of linguistics, the vernacular plainchant follows the three parameters of prosody: (1) the temporal parameter, (2) the dynamic parameter, and (3) the intonation parameter, while pronouncing the texts of the Holy Scriptures and realising as well as considering these three parameters in shaping the melodic information and bearing it in mind in performance. In terms of Christian piety, the vernacular plainchant is a monodic musical a cappella pronunciation of the unaltered prose texts of the Holy Scriptures, which is based on prayerful concentration and/ or sacred conviction, and is trying to follow in every point the authority of the Word of God and consider the prosodic peculiarities of a particular language.

The contemplative style is based on "switching off" the personal prosodic intonations of the text. To a certain extent the result resembles a phenomenon that is known in music performance as "recitation". However, it differs from recitation, because there is no intention of a performer to express him- or herself through music. The result that is similar to recitation happens simply because the performer begins to say the syllables at the same height without any intention to sing. Melodic formulas are then applied to this recitation-like contemplative talking.

There are two kinds of melodic formulas in Western plainchant: (1) formulas with accentual cadences, and (2) formulas with cursive cadences. Accentual cadence takes into consideration the prosodic principles of Latin as well as other Indo-European languages in which an accented syllable is usually perceived as the longest syllable of a word. This means that the accented syllables are always marked with dominant notes of a cadence. 
Cursive cadence, on the other hand, always applies the same amount of syllables in the cadences without any accentual considerations. Estonian prosody differs significantly from Indo-European prosody, as the accented syllable is not always the longest syllable of the word. Therefore, in Estonian formula-based plainchant a cursive principle should be preferred.

While the contemplative style stands on "switching off" personal prosodic interpretation, the declarative style attempts to achieve the opposite: personal conviction in pronouncing the text should be enhanced and extracted as a melody. The free style is a further development of the declarative style, in which the composer decorates the melody according to his or her personal creativity and taste.

Describing the contemplative, declarative, and free styles of Estonian plainchant showed that we are dealing with a genre of extensive possibilities, which appreciates our mother tongue, recognises the tradition from which our musical culture springs, and gives a dignified position to the core text of the Estonian language and culture - the Bible. 